\title{
Malic acid combined with heat treatment to protect protein from soybean meal against rumen degradation
}

\author{
Mahfoud OUARTI, Javier GonZÁLEZ*, Luis Filipe Jorge FERNANDES, \\ Maria Remedios ALviR, Carlos Alberto RodRíGUEZ
}

\author{
Departamento de Producción Animal, Escuela Técnica Superior de Ingenieros Agrónomos, Universidad \\ Politécnica de Madrid, Ciudad Universitaria, 28040 Madrid, Spain
}

(Received 27 January 2005 - Accepted 2 February 2006)

\begin{abstract}
The protection of proteins from soybean meal (SBM) by treatments with solutions of malic acid (at two crescent doses) and heat was studied in a $3 \times 3$ Latin-square design using three diets and three wethers cannulated in the rumen and in the duodenum. Solutions 2.25 and $4.50 \mathrm{~N}$ of malic acid were pulverised $\left(400 \mathrm{~mL} \cdot \mathrm{kg}^{-1}\right)$ on SBM under continuous mixing. Then, the treated meals were dried in an oven at $117^{\circ} \mathrm{C}$ for 6 hours. The diets were isoproteic and included $55 \%$ lucerne hay and $45 \%$ concentrate, with untreated (UT) and treated SBM (T2.25N and T4.50N). The diets were distributed, at $50 \mathrm{~g} \cdot \mathrm{kg}^{-1} \mathrm{BW}^{0.75}$, in six equal meals (every $4 \mathrm{~h}$ ). The estimates of ruminal effective degradability (ED) of dry matter (DM) and crude protein $(\mathrm{CP})$ of SBM samples were obtained using in situ and rumen outflow methods, whereas the intestinal digestibility (ID) was determined by the mobile nylon bag technique on residues incubated in the rumen for $8 \mathrm{~h}$. The effects of the addition of malic acid in the diet on rumen fermentation patterns and fibrolitic activity (measured by the in situ degradation of the lucerne hay) were also determined. The treatments did not alter the digestive transit kinetics of SBM particles, which showed rumen outflow rates in the interval from 5.5 to $6.1 \% \cdot \mathrm{h}^{-1}$. Degradation of CP showed a sigmoidal shape in all samples and was described well with a simple exponential model, based on a constant fractional degradation rate $\left(k_{d}\right)$, or using a logistic model in which the fractional degradation rate increases with time from an initial $\left(k_{\mathrm{o}}\right)$ to a final $\left(k_{\infty}\right)$ value. According to the first model, the $k_{d}$ value corresponding to the protective treatments showed a tendency $(P=0.054)$ to decrease with the treatments (from 4.71 to 3.32 and $3.35 \% \cdot \mathrm{h}^{-1}$ for UT, T2.25N and T4.50N, respectively). In the second model, this deceleration of CP degradation only affected $k_{\mathrm{o}}(P=0.039)$, whereas, no effect was observed on $k_{\infty}$. These changes reduced moderately the ED of CP of the treated samples (15-16\%) in relation to the untreated SBM, although differences were not significant $(46.2,39.3$ and 38.5\%, respectively, as mean of both models). No effect was observed for the ID of CP with values shown between 99.0 and $99.4 \%$. Including malic acid in the diet did not have an important effect on the degradation of $\mathrm{DM}$ and fibre fractions of lucerne hay or on the parameters of ruminal fermentation, except for a decrease $(P=0.050)$ of the acetic acid:propionic acid ratio $(4.44,3.53$, and 3.78 for UT, T2.25N and $\mathrm{T} 4.50 \mathrm{~N}$, respectively).
\end{abstract}

protein protection / soybean meal / malic acid / heat / effective degradability / intestinal digestibility

\footnotetext{
*Corresponding author: javier.gonzalez@upm.es
} 
Résumé - L'acide malique associé au traitement thermique pour protéger les protéines issues du tourteau de soja des dégradations ruminales. La protection des protéines du tourteau de soja par des traitements combinant des solutions d'acide malique (à deux doses croissantes) et la chaleur a été étudiée selon un dispositif en carré latin $3 \times 3$ avec trois régimes et trois moutons castrés porteurs de canules du rumen et du duodénum. Des solutions de 2,25 et 4,50 $\mathrm{N}$ d'acide malique ont été pulvérisées $\left(400 \mathrm{~mL} \cdot \mathrm{kg}^{-1}\right)$ sur le tourteau de soja sous malaxage continu. Puis, les tourteaux traités ont été séchés dans un four à $117^{\circ} \mathrm{C}$ pendant 6 heures. Les rations étaient isoprotéiques et ont inclus $55 \%$ de foin de luzerne et $45 \%$ de concentré, avec du tourteau de soja non traité (UT) ou traité (T2.25N et T4.50N). Les rations ont été distribuées, à $50 \mathrm{~g} \cdot \mathrm{kg} \mathrm{BW}^{-0,75}$, en six repas égaux (toutes les quatre heures). L'estimation de la dégradabilité théorique (DT) ruminale de la matière sèche et des matières azotées totales (MAT) des échantillons du tourteau de soja a été obtenue en utilisant la technique in situ et de passage des particules hors du rumen, tandis que la digestibilité intestinale (DI) a été déterminée par la méthode des sachets de nylon sur les résidus incubés dans le rumen pendant 8 heures. Les effets de l'addition de l'acide malique dans la ration sur les voies de fermentation dans le rumen et l'activité fibrolytique (mesurée par dégradation in situ du foin de luzerne) ont également été évalués. Les traitements n'ont pas altéré la cinétique de transit digestif des particules du tourteau de soja, pour lesquelles le taux de sortie du rumen a été compris entre 5,5 et $6,1 \% \cdot \mathrm{h}^{-1}$. La courbe de dégradation des MAT a eu une forme sigmoïde pour tous les échantillons et a bien été décrite avec un modèle exponentiel simple, basé sur une vitesse de dégradation partielle constante $\left(k_{d}\right)$; ou en utilisant un modèle logistique dans lequel la vitesse de dégradation partielle augmente avec le temps d'une valeur initiale $\left(k_{\mathrm{o}}\right)$ à une valeur finale $\left(k_{\infty}\right)$. Selon le premier modèle, la valeur $k_{d}$ correspondant aux traitements protecteurs tend à diminuer $(P=0,054)$ avec les traitements $\left(\right.$ de 4,41 à 3,32 et $3,35 \% \cdot h^{-1}$ pour, respectivement, UT, T2.25N et T4.50N). Dans le second modèle, cette réduction de la vitesse de la dégradation des MAT a seulement affecté $k_{\mathrm{o}}(P=0,039)$, tandis qu'aucun effet n'a été observé pour $k_{\infty}$. Ces changements ont modérément réduit la dégradabilité théorique des MAT des échantillons traités (15-16\%) par rapport aux échantillons non traités, bien que les différences n'aient pas été significatives (46,2, 39,3 et 38,5, respectivement, comme moyennes des deux modèles). Aucun effet n'a été observé pour la digestibilité intestinale des MAT, qui a eu des valeurs comprises entre 99,0 et 99,4\%. L'incorporation d'acide malique dans la ration n'a pas eu d'effet considérable sur la dégradation de la MS et les fractions ligno-cellulosique ou sur les paramètres des fermentations ruminales, excepté une diminution $(P=0,050)$ du rapport acide acétique/acide propionique $(4,44,3,53$, et 3,78 , respectivement, pour UT, T2.25N et T4.50N).

protection des protéines / tourteau de soja / acide malique / chaleur / dégradabilité théorique / digestibilité intestinale

\section{INTRODUCTION}

In ruminants, the utilisation efficiency of good quality proteins from concentrates such as soybean meal (SBM) is largely reduced through their partial fermentation by ruminal microorganisms and the generation of nitrogenous compounds other than amino acids and therefore of low metabolic value for the animal (losses of ammonia from the rumen, microbial nucleic acids, amino sugars, ... ). As a result, efforts have been made to protect good quality proteins from microbial actions. In SBM, obtained by solvent extraction, an important fraction of the CP (60-70\%) is usually de- graded in the rumen $[12,16,22]$ and therefore, protection is of interest. Denaturation of proteins through treatment with acid solutions have been essayed with this purpose on different feeds $[5,25,26]$, generally showing positive effects. However, little is known about several aspects of this technique (type of acids, doses, effects of diet on protection efficiency, ...). Alternatively, heat treatment of feeds is commonly used to protect protein, based on protein denaturation and through condensation reactions between proteins and carbohydrates [9]. As a consequence of these effects, both treatments decelerate protein breakdown and reduce degradability. The 
combined use of both treatments may allow a high level of protein protection with nutritional and economic advantages such as lower acid doses, reduced cost of the thermal treatment or less risk of irreversible Maillard reactions, associated with protein over-protection. The use of malic acid for this purpose is of interest since this acid (or malate) is an intermediate product of the Krebs cycle and of the metabolic route transforming pyruvate into propionate. Nisbert and Martin $[17,18]$ showed that malate stimulates the activity and growth of Selenomonas ruminantium and therefore, improves the captation by these bacteria of lactic acid to be transformed into propionic acid, which is of high importance in concentrate based diets. However, the positive effects of malate have been shown with in vitro studies [7, $8]$, whereas the in vivo effects are confusing [15].

The objective of this study was to essay the interest of the protection of protein from soybean meal (SBM) by treatments with solutions of malic acid (at two increasing doses) and heat. Since malic acid might modify rumen fermentation, the effects on rumen fermentation of this combined acid-heat treatment has also been considered.

\section{MATERIALS AND METHODS}

\subsection{Soybean meal treatments, animals and feeding}

The SBM was treated with solutions $\left(400 \mathrm{~mL} \cdot \mathrm{kg}^{-1}\right)$ of malic acid (DL-malic acid, E-296, PANREAC S.A. FW = $\left.134.1 \mathrm{~g} \cdot \mathrm{mole}^{-1}\right) 2.25$ and $4.50 \mathrm{~N}$ (150.9 and $301.7 \mathrm{~g} \cdot \mathrm{L}^{-1}$ ) with resulting measured densities of 1.064 and $1.112 \mathrm{~g} \cdot \mathrm{mL}^{-1}$, respectively. SBM was pulverised in a mixer with the malic acid solutions. The process was terminated when the weight, lost in the pulverizer, equalled the weight of the dose intended to apply, as calculated from
Table I. Raw material composition (\% of DM) of concentrates.

\begin{tabular}{|c|c|c|c|}
\hline Diet & UT & $\mathrm{T} 2.25 \mathrm{~N}$ & $\mathrm{~T} 4.50 \mathrm{~N}$ \\
\hline Barley grain & 89.25 & 88.75 & 88.25 \\
\hline $\begin{array}{l}\text { Soybean meal (SBM, } \\
\text { untreated or treated) }\end{array}$ & 8.92 & 9.42 & 9.92 \\
\hline Minerals and vitamins ${ }^{1}$ & 1.83 & 1.83 & 1.83 \\
\hline
\end{tabular}

${ }^{1}$ Sodium bicarbonate: $0.83 \%$; calcium carbonate: $0.40 \%$; sodium chloride: $0.30 \%$; premix of vitamins and trace minerals: $0.30 \%$.

UT: untreated SBM; T2.25N and T4.50N: SBM treated with 2.25 and $4.50 \mathrm{~N}$ solutions of malic acid.

the previously indicated density. Next, the SBM stayed resting for one hour before being dried in a forced air oven for $6 \mathrm{~h}$ at $117^{\circ} \mathrm{C}$, stirring the material every $30 \mathrm{~min}$ utes. Untreated and treated SBM were used to elaborate three diets (UT, T2.25N and $\mathrm{T} 4.50 \mathrm{~N})$. These diets included a $55 \%$ lucerne hay and $45 \%$ concentrate, containing barley grain, the respective SBM, minerals and vitamins (Tab. I). The chemical composition of SBM and changes provoked by the treatments are presented in detail in the results' section. Concentrations $\left(\mathrm{g} \cdot \mathrm{kg}^{-1} \mathrm{DM}\right)$ for $\mathrm{CP}$, neutral detergent fibre (NDF), acid detergent fibre (ADF) and acid detergent lignin (ADL) were respectively $168,492,359$ and 86.0 in lucerne hay and 157, 195, 49.9 and 11.0 in barley grain. The diets were isoproteic and contained (per kg DM) $180 \mathrm{~g} \mathrm{CP}$ and about $300 \mathrm{~g}$ NDF. The level of DM intake was fixed at $50 \mathrm{~g} \cdot \mathrm{kg}^{-1} \mathrm{LW}^{0.75}$ and the diet was distributed in six equal meals (every $4 \mathrm{~h}$ ), starting at 9:00 h. Three Manchega wethers fitted with rumen cannulae and " $T$ " duodenal simple cannulae were randomly allocated to the above diets in a $3 \times 3$ Latinsquare design in order to estimate the rumen degradation and the intestinal digestion of SBM samples as well as the effects of added malic acid to the diet on ruminal fermentation. 


\subsection{Experimental procedures}

In order to determine the rumen particulate outflow rate, the different SBM samples were previously washed to eliminate the soluble components and marked by immersion in solutions of $\mathrm{YbCl}_{3}$ at a dose of $10 \mathrm{mg} \mathrm{Yb} \cdot \mathrm{g}^{-1}$ of feed as described by González et al. [11]. After a 10-day period to adapt to the diet, a pulse dose (40 g) of labelled SBM was fed to each animal immediately before the first daily meal. A total of 21 samples were obtained through the duodenal cannula, the first sample before supplying the marker and the remainder between 1 and $82 \mathrm{~h}$ afterwards. These samples were dried, milled and analysed for $\mathrm{Yb}$. The pattern of $\mathrm{Yb}$ concentrations in the duodenal digesta over time was described for each animal by the model of Grovum and Williams [13]: $\mathrm{C}=\mathrm{A}\left(\mathrm{e}^{\left(-k_{1}(t-T)\right)}-\mathrm{e}^{\left(-k_{2}(t-T)\right)}\right)$. The rate constants derived from the decreasing phase of concentrations $\left(k_{1}\right)$ were used as the rate of outflow from the rumen $\left(k_{\mathrm{p}}\right)$ to determine the values of effective degradability (ED).

Nylon bags with a pore size of $46 \mu \mathrm{m}$ and $11 \times 7 \mathrm{~cm}$ (inner dimensions) were filled with approximately $3 \mathrm{~g}$ (air-dry basis) of the different SBM samples (grounded to pass a $2 \mathrm{~mm}$ screen). The bags were incubated in the rumen for periods of $2,4,8,16,24$, and $48 \mathrm{~h}$ in two series of incubation. In each series, duplicate bags were incubated for the $8 \mathrm{~h}$ period. At each series of incubation, all bags were placed simultaneously in the rumen just before the wethers were offered their first meal in the morning. After being collected from the rumen, the bags were washed with tap water and stored at $-20{ }^{\circ} \mathrm{C}$. After thawing, the bags were washed three times for 5 minutes in a turbine washing machine. The same washing procedure was applied to two bags to obtain the zero hours value. The bags were oven dried for $48 \mathrm{~h}$ at $80{ }^{\circ} \mathrm{C}$ and analysed for DM and CP in order to establish degradation kinetics ex- cept one of the replicates of $8 \mathrm{~h}$, which was stored at $-20{ }^{\circ} \mathrm{C}$ and freeze-dried to be employed in intestinal digestibility studies. Microbial contamination of the bags was not estimated. In order to determine intestinal digestibility, the two bags obtained in each animal in both incubation series were pooled. These samples were analysed for DM and CP and four sub-samples of about $200 \mathrm{mg}$ were weighed into mobile nylon bags, with an approximately round shape $(\varnothing \approx 3 \mathrm{~cm})$. These bags were introduced through the duodenal cannula into the small intestine (at a rate of one bag every $15 \mathrm{~min}$ ) and recovered from the faeces. The bags were then conditioned, stored, washed, dried, and weighed as described above and then pooled and analysed for $\mathrm{CP}$ in order to calculate the disappearance from the bag.

In each rumen incubation series, a bag filled with approximately $3 \mathrm{~g}$ (air-dry basis) of the lucerne hay employed in the diet was also included for $24 \mathrm{~h}$ of incubation in order to measure the effect of including malic acid on rumen fibrolytic capacity. These bags were washed as indicated above, freeze-dried and analysed for NDF and ADF.

For each animal, the disappearance of $\mathrm{DM}$ or $\mathrm{CP}$ from SBM during rumen incubation was fit to the model of Ørskov and McDonald [19]: $d=a+b\left(1-\mathrm{e}^{-k d t}\right)$. In addition, since the disappearance of $\mathrm{CP}$ showed a sigmoidal shape, these data were also described using the logistic model of Van Milgen and Beaumont [23], which, as indicated by Gomez [10], can be described by the expression: $d=a+(b(1-$ $\left.\left.\mathrm{e}^{-k_{\infty} t}\right) /\left(1+\left(\left(k_{\infty}-k_{\mathrm{o}}\right) / k_{\mathrm{o}}\right) \mathrm{e}^{-k_{\infty} t}\right)\right)$.

For both models, the constants $a$ and $b$ represent the soluble and the non-soluble degradable fractions, respectively. In the exponential model [19], $k_{d}$ represents the constant fractional degradation rate of the $b$ fraction. Conversely, in the logistic model [23] the fractional degradation rate increased with time from $k_{\mathrm{o}}$ to $k_{\infty}$. Some 
constraints were necessary to fit these degradation kinetics. Thus, for both models, the total degradable fraction $(a+b)$ was assumed to be $100 \%$, when the sum of $a$ and $b$, as estimated from the initial regression, was above $100 \%$. In addition, in the logistic model $a$ was assumed to be the disappearance mean value at $0 \mathrm{~h}$.

The effective degradability (ED) of DM and $\mathrm{CP}$ was estimated by using the above equations and the rumen particulate outflow rate $\left(k_{\mathrm{p}}\right)$ according to the integration method proposed by Ørskov and McDonald [19]. Thus, when the degradation was described with the exponential model, the ED was calculated as follows:

$\mathrm{ED}=a+\left(b \times k_{d} /\left(k_{d}+k_{p}\right)\right)$.

The application of this method to the logistic equation leads to the equation [10]: $\mathrm{ED}=a+\int_{0}^{\infty} \mathrm{e}^{-k_{p} \mathrm{t}}(\mathrm{d} d / \mathrm{dt}) \mathrm{dt}=a+$ $b k_{\mathrm{o}} k_{\infty}^{2} \int_{o}^{\infty}\left(\mathrm{e}^{-\left(k_{p}+k_{\infty}\right) \mathrm{t}} /\left(k_{\mathrm{o}}+\left(k_{\infty}-k_{\mathrm{o}}\right) \mathrm{e}^{-k_{\infty} \mathrm{t}}\right)^{2}\right)$.

The primitive function of this integral was not found and therefore ED values were determined by mathematical approximation using a mathematical calculation software (Derive 2; Soft Warehouse Inc., Honolulu, USA).

Between transit and degradation studies (on day 5 of the experimental period), samples of rumen fluid were collected hourly in the interval between the two morning meals in order to determine rumen $\mathrm{pH}$ and ammonia and volatile fatty acid (VFA) concentrations.

\subsection{Chemical analyses}

The untreated SBM was analysed for DM, ash, ether extract and CP (Dumas $\mathrm{N} \times 6.25)$ by the methods of the Association of Official Analytical Chemists [4], and for NDF [24], ADF, and ADL [21]. The insoluble nitrogen in neutral detergent (NDIN) and in acid detergent (ADIN) solutions was determined by $\mathrm{N}$ analysis of the NDF and ADF residues, respectively.
Treated SBM samples and rumen incubated residues and intestinal mobile nylon bags were also analysed for $\mathrm{N}$ by the Dumas method. Analysis of NDF and ADF in the lucerne hay and in rumen incubated residues were also performed by the methods indicated. Samples of duodenal content collected for transit studies were analysed for $\mathrm{Yb}$ by atomic absorption spectrometry, as described by González et al. [11].

Ammonia in rumen fluid was analysed by distillation with a solution of sodium tetraborate $(2.5 \% \mathrm{w} / \mathrm{v})$, collected on boric acid solution $(1 \% \mathrm{w} / \mathrm{v})$ and titrated with hydrochloric acid (0.02M). Rumen fluid VFA concentration was determined in a Hewlett-Packard 5710 A (HewlettPackard, Palo Alto, CA, USA) gas chromatograph with a flame ionisation detector.

\subsection{Statistical methods}

The different kinetics associated with the employed models were fitted using a non-linear regression model. The results of degradation parameters of DM and $\mathrm{CP}$ as well as those of ED and ID were compared by variance analysis with treatments $(T)$, periods $(P)$ and wethers $(W)$ in the model $\left(y=\mu+T_{\mathrm{i}}+P_{\mathrm{j}}+W_{\mathrm{k}}+\xi_{\mathrm{ijk}}\right)$. Since the experiment was designed to test the practical effects of the combined treatment, the effects of heat and acid cannot be separated. Thus, the means were examined by orthogonal contrasts for the effect of the treatment (UT vs. T2.25N, T4.5N) and of the malic acid dose (T2.25N vs. T4.5N). These same procedures were also employed to study the results of degradation of DM, NDF and ADF from lucerne hay after $24 \mathrm{~h}$ of rumen incubation and those characterising the ruminal fermentation. All the statistical analyses were performed using the Statistical Analysis System for Windows software, version 6.12 (SAS Institute Inc., Cary, NC, USA). 
Table II. Effect of treatments on the transit of soybean meal particles.

\begin{tabular}{lcccccc}
\hline Item $^{1}$ & UT & T2.25N & T4.50N & MSE & $T$ & $D$ \\
\hline$k_{1}\left(\% \cdot \mathrm{h}^{-1}\right)$ & 5.87 & 5.55 & 6.13 & 0.98 & 0.981 & 0.717 \\
$k_{2}\left(\% \cdot \mathrm{h}^{-1}\right)$ & 35.7 & 42.4 & 32.2 & 9.23 & 0.901 & 0.516 \\
$T(\mathrm{~h})$ & 1.23 & 1.41 & 1.41 & 0.20 & 0.530 & 0.994 \\
$M R T(\mathrm{~h})$ & 22.0 & 23.9 & 24.5 & 1.62 & 0.378 & 0.804 \\
\hline
\end{tabular}

${ }^{1}$ Parameters from Grovum and Williams [13]: $\mathrm{C}=\mathrm{A}\left(\mathrm{e}^{\left(-k_{1}(t-T)\right)}-\mathrm{e}^{\left(-k_{2}(t-T)\right)}\right)$.

$k_{1}$ rumen particulate outflow rate; $k_{2}$ secondary rate constant, $T$ : transit time; MRT: mean retention time $=$ $\left(100 / k_{1}\right)+\left(100 / k_{2}\right)+T$.

MSE: mean standard error; $T$ : probability of the orthogonal contrast UT vs. T2.25N, T4.5N; $D$ : probability of the orthogonal contrast T2.25N vs. T4.5N. For other abbreviations see Table I.

\section{RESULTS}

The chemical characterisation of the untreated SBM sample was the following $\left(\mathrm{g} \cdot \mathrm{kg}^{-1} \mathrm{DM}\right): \mathrm{OM}=930, \mathrm{EE}=22.9, \mathrm{CP}=$ $505, \mathrm{NDF}=138, \mathrm{ADF}=52.1, \mathrm{ADL}=$ 7.95. The proportions (\%) of NDIN and ADIN on total $\mathrm{N}$ were 12.1 and 0.33 , respectively. The $\mathrm{CP}$ content of this meal was diluted to 476 and $456 \mathrm{~g} \cdot \mathrm{kg}^{-1} \mathrm{DM}$ in meals $\mathrm{T} 2.25 \mathrm{~N}$ and $\mathrm{T} 4.50 \mathrm{~N}$, (respectively) after incorporating the malic acid solutions.

The parameters of the digestive transit kinetics of SBM particles (Tab. II) were similar for all treatments. Values of $k_{1}$, considered as rumen outflow rates, ranged from 5.5 to $6.1 \% \cdot \mathrm{h}^{-1}$, whereas the mean retention time in the stomachs varied from 22.0 to $24.5 \mathrm{~h}$.

Mean values of the degradation kinetic parameters of DM and $\mathrm{CP}$ and ED estimates are shown in Table III together with the ID values of the residues remaining after $8 \mathrm{~h}$ of incubation in the rumen.

The only variation observed in the degradation of DM was an increase $(P=$ 0.004 ) of the soluble fraction upon heat and malic acid treatment, without an effect of the applied malic acid dose $(29.5,32.0$, and $33.3 \%$ for UT, T2.25N and T4.50N, respectively). This variation was mathematically transferred to the potentially degradable fraction. However, these changes did not have any effect on the ED of DM whose values ranged between 61.0 and $61.9 \%$. The intestinal digestibility of the DM was also similar in all diets (from 92.0 to $92.8 \%$ ), although some tendencies were detected as a consequence of the very low MSE recorded.

Untreated and treated SBM samples had a low content of soluble $\mathrm{CP}$, given the washout values $(4.60,4.99$ and $5.64 \%$ for UT, T2.25N and T4.50N, respectively) and the $a$ fraction estimated with the exponential model $(2.19,3.29$ and $1.81 \%$, respectively). According to this model, the $\mathrm{CP}$ degradation rate tended to decrease $(P=0.054)$ with the treatments from 4.71 to 3.32 and $3.35 \% \cdot \mathrm{h}^{-1}(\mathrm{UT}, \mathrm{T} 2.25 \mathrm{~N}$ and $\mathrm{T} 4.50 \mathrm{~N}$, respectively). This deceleration moderately reduced $(15-16 \%)$ the values of ED in treated samples, although the differences compared to the untreated sample were not significant. The application of the logistic model limited the effects of the treatments to the initial rate of degradation $\left(k_{\mathrm{o}}\right)$ that registered a decrease $(P=0.039)$. On the contrary, no effect was observed on the final rate of degradation $\left(k_{\infty}\right)$. However, this model led to lower values of ED than the previous model $(\mathrm{MSE}=0.34$; $P=0.070)$. No effect was observed for the ID of CP, which showed values between 99.0 and $99.4 \%$. 
Table III. Effect of treatments on degradation kinetics ${ }^{1}$ and effective degradability (ED) in the rumen and on intestinal digestibility ${ }^{2}$ (ID) of dry matter and crude protein of soybean meal samples.

\begin{tabular}{|c|c|c|c|c|c|c|}
\hline Item & UT & $\mathrm{T} 2.25 \mathrm{~N}$ & $\mathrm{~T} 4.50 \mathrm{~N}$ & MSE & $T$ & $D$ \\
\hline \multicolumn{7}{|l|}{ Dry matter } \\
\hline \multicolumn{7}{|c|}{ Model of Ørskov and McDonald (1979) [19] } \\
\hline$a(\%)$ & 29.5 & 32.0 & 33.3 & 0.54 & 0.004 & 0.240 \\
\hline$k_{d}\left(\% \cdot \mathrm{h}^{-1}\right)$ & 4.87 & 4.10 & 3.98 & 0.32 & 0.166 & 0.804 \\
\hline $\mathrm{ED}(\%)$ & 61.9 & 61.0 & 61.9 & 3.89 & 0.926 & 0.880 \\
\hline ID $(\%)$ & 92.0 & 92.8 & 92.2 & 0.12 & 0.092 & 0.073 \\
\hline \multicolumn{7}{|l|}{ Crude protein } \\
\hline \multicolumn{7}{|c|}{ Model of Ørskov and McDonald (1979) [19] } \\
\hline$a(\%)$ & 2.19 & 3.29 & 1.81 & 0.70 & 0.714 & 0.276 \\
\hline$k_{d}\left(\% \cdot \mathrm{h}^{-1}\right)$ & 4.71 & 3.32 & 3.35 & 0.27 & 0.054 & 0.941 \\
\hline $\mathrm{ED}(\%)$ & 46.5 & 39.5 & 39.0 & 4.97 & 0.357 & 0.950 \\
\hline \multicolumn{7}{|c|}{ Model of Van Milgen and Baumont (1995) [23]* } \\
\hline$k_{\mathrm{o}}(\%)$ & 2.71 & 2.15 & 1.32 & 0.16 & 0.039 & 0.070 \\
\hline$k_{\infty}(\%)$ & 9.02 & 6.35 & 8.95 & 0.84 & 0.313 & 0.160 \\
\hline $\mathrm{ED}(\%)$ & 45.9 & 39.1 & 37.9 & 5.37 & 0.378 & 0.896 \\
\hline ID $(\%)$ & 99.2 & 99.4 & 99.0 & 0.24 & 0.872 & 0.316 \\
\hline
\end{tabular}

${ }^{1}$ Assumed $a+b=100$. Consequently, $b$ values have been omitted.

${ }^{2}$ Of undegraded residues after $8 \mathrm{~h}$ of rumen incubation.

* Assuming zero-hours as $a$ values: $4.60,4.99$ and $5.64 \%$, for UT, T2.25N and T4.50N, respectively. $a$ and $b$ represent the soluble and the non-soluble degradable fractions, respectively. $k_{d}$ : constant degradation rate; $k_{\mathrm{o}}$ : initial degradation rate; $k_{\infty}$ : final degradation rate. MSE: mean standard error; $T$ : probability of the orthogonal contrast UT vs. T2.25N, T4.5N; $D$ : probability of the orthogonal contrast T2.25N vs. T4.5N. For other abbreviations see Table I.

The inclusion of malic acid in the diet did not have any effect on the $24 \mathrm{~h}$ degradation of DM and fibre of the lucerne hay (Tab. IV), with mean values for the three diets of $57.8,25.5$, and $21.0 \%$, for DM, NDF and ADF, respectively. Malic acid and heat treatment did not alter the mean $\mathrm{pH}$ value of the rumen liquid in the interval between meals (on average 6.29) or the concentration of total VFA (on average $89.8 \mathrm{mM} \cdot \mathrm{L}^{-1}$ ) or ammonia, although a lower $(P=0.051)$ ammonia concentration was observed upon feeding of T4.50N $\left(258,260\right.$ and $237 \mathrm{mg} \mathrm{N}-\mathrm{NH}_{3} \cdot \mathrm{L}^{-1}$ for UT, T2.25N and T4.50N, respectively) (Tab. V). No effects were observed on the fermentation pattern except for a tendency $(P=0.077)$ to increase the propionic acid proportion. As a consequence, a lower
Table IV. Effect of the treatments on the degradation $^{1}(\%)$ of dry matter (DM), neutral detergent fibre (NDF) and acid detergent fibre $(\mathrm{ADF})$ of the lucerne hay diet.

\begin{tabular}{lcccccc}
\hline Item & UT & T2.25N & T4.50N & MSE & $T$ & D \\
\hline DM & 56.9 & 57.2 & 59.4 & 3.12 & 0.746 & 0.660 \\
NDF & 24.5 & 24.6 & 27.3 & 5.27 & 0.850 & 0.750 \\
ADF & 20.5 & 20.2 & 22.3 & 6.10 & 0.932 & 0.827 \\
\hline
\end{tabular}

${ }^{1}$ After $24 \mathrm{~h}$ of rumen incubation.

MSE: mean standard error. $T$ : probability of the orthogonal contrast UT vs. T2.25N, T4.5N; $D$ : probability of the orthogonal contrast $\mathrm{T} 2.25 \mathrm{~N}$ vs. T4.5N. For other abbreviations see Table I.

$(P=0.050)$ acetic acid: propionic acid ratio was observed $(4.44,3.53$ and 3.78 for UT, T2.25N and T4.50N diets, respectively). 
Table V. Effect of treatments on mean rumen $\mathrm{pH}$, ammonia-N and volatile fatty acids (VFA).

\begin{tabular}{lcccccc}
\hline Item & UT & T2.25N & T4.50N & MSE & $T$ & $D$ \\
\hline $\mathrm{pH}$ & 6.37 & 6.22 & 6.29 & 0.048 & 0.195 & 0.416 \\
$\mathrm{NH}_{3}-\mathrm{N}\left(\mathrm{mg} \mathrm{N} \cdot \mathrm{L}^{-1}\right)$ & 258 & 260 & 237 & 3.81 & 0.178 & 0.051 \\
Total-VFA $\left(\mathrm{mM} \cdot \mathrm{L}^{-1}\right)$ & 89.8 & 93.9 & 85.6 & 7.71 & 0.997 & 0.528 \\
Individual VFA (molar \% of total) & & & & & & \\
$\quad$ Acetic acid & 62.6 & 61.1 & 61.0 & 0.82 & 0.261 & 0.931 \\
$\quad$ Propionic acid & 14.1 & 17.5 & 16.2 & 0.65 & 0.077 & 0.292 \\
$\quad$ Butyric acid & 19.3 & 17.5 & 18.8 & 0.77 & 0.356 & 0.369 \\
$\quad$ Isovaleric acid & 1.39 & 1.30 & 1.54 & 0.086 & 0.802 & 0.186 \\
$\quad$ Valeric acid & 2.59 & 2.57 & 2.49 & 0.105 & 0.670 & 0.643 \\
Acetic acid/propionic acid & 4.44 & 3.53 & 3.78 & 0.151 & 0.050 & 0.358 \\
\hline
\end{tabular}

MSE: mean standard error; $T$ : probability of the orthogonal contrast UT vs. T2.25N, T4.5N; $D$ : probability of the orthogonal contrast T2.25N vs. T4.5N. For other abbreviations see Table I.

\section{DISCUSSION}

The chemical composition of the untreated SBM generally agrees with data reported in various feed tables [2, 16, 22], although this sample showed a high proportion of NDIN. In fact, based on the values of NDIN, about $44 \%$ of the estimated NDF may be CP in this tested sample. A high proportion of NDIN is normal after important thermal treatments [20] as a consequence of the reduced protein solubility associated with denaturalisation of some proteins. In this line, the observed values of NDIN and ADIN were intermediate between those indicated by the National Research Council [16] for solvent SBM and non-enzymatically browned SBM.

Degradation in the rumen of SBM is extensive. Consequently, as observed in the present study, non biological asymptotic values $(a+b)$ above $100 \%$ are often observed in the literature, when this restriction is not introduced [12].

The increased DM soluble fraction may be attributed to the solubility in the rumen liquid of the malate incorporated with the treatment. As a result, these changes did not affect the appreciation of the true nutritional characteristics of the feed, and the
ED of DM was not significantly affected. Assuming that the ED of OM should be similar to that of DM, these results show that the synthesis of microbial protein from the fermentation of this sample should not be influenced by these treatments. Recorded ED values were somewhat lower than those observed by González et al. [12] for 8 solvent-extracted SBM, which varied from 63.6 to $69.5 \%$ with a mean value of $66.4 \%$. This disagreement may be a consequence of the low degradability observed for $\mathrm{CP}$ in all the tested meals, due to the importance of this constituent in this feed and especially in the non degraded fraction.

The deceleration of the degradation of insoluble $\mathrm{CP}$ with the protective treatments shows an increased resistance to the actions of microorganisms. This fact is a consequence of the denaturalisation of proteins by addition of acid and heat treatment and by possible reactions of condensation of the proteins with other feed components resulting from the heat application under humid conditions. However, the associated reduction of the ED of CP was only moderate $(15-16 \%)$. This may be due to the special chemical and degradative characteristics of the untreated SBM 
used in this study, which does not correspond with those reported in the literature for SBM extracted with solvents. Indeed, the ED of CP usually is higher than $60 \%$ $[12,22]$ whereas in the current study, this value was as low as $46.5 \%$ for the untreated SBM. As indicated above, the other special characteristic of this meal was the very high value for NDIN (12.1\%). Andres and González [1] found a negative relation between the ED of $\mathrm{CP}$ and NDIN. Similarly, González et al. [12] observed, for 8 solvent extracted SBM, a range of values from 1.9 to $6.9 \%$ for NDIN and from 56 to $67 \%$ for the ED of CP, whereas the respective values for the only tested expeller meal were $9.0 \%$ and $46 \%$. Consequently, we may consider that the untreated SBM employed was obtained by a procedure involving the exposure to high temperatures. Additional evidences are the low values of CP solubility (as observed for non-enzymatically browned SBM [16]) and the sigmoid evolution of the CP degradation of the untreated SBM, which is not often reported in the literature for solvent meals. It is noteworthy that the test treatments increased the sigmoid character of the CP degradation, as indicated by the increased ratio $\left(k_{\infty}-k_{\mathrm{o}}\right) / k_{\mathrm{o}}[10]$, provoked by the reduced $k_{\mathrm{o}}$. Consequently, the results of this experiment may be considered promising for the protective effect of the proposed treatments, regarding the higher CP ED of more conventional SBM samples. In this line, recent results of a similar treatment led to an important reduction of the ED of $\mathrm{CP}$ of a sunflower meal sample (from 79.6 to $38.4 \%, P=0.003$ ) [3]. However, these treatments do not affect the intestinal availability of the rumen undegraded CP. Although these values were only determined for a discrete time $(8 \mathrm{~h})$, they may be considered as representative of the total undegraded protein since the ID of CP of this feed is not affected by the rumen incubation time $[6,12]$. The values of ID for $\mathrm{CP}$ in SBM samples were in good agree- ment with previous works [6, 12, 14, 27]. The very high ID values of $\mathrm{CP}$ also suggest a low concentration of undigestible nitrogen compounds that agree with the very low proportion of ADIN recorded in the original SBM sample.

The similar degradation values of DM and fibre fractions of the lucerne hay imply that the addition of malic acid to the diet does not alter the efficiency of the rumen fibrolytic population. In the same manner, this addition had no effects on the $\mathrm{pH}$ of the rumen liquid, which was in agreement with this last fact and with the similar total VFA concentrations. On the contrary, malic acid had some effect on the fermentation pattern, as shown by the reduction of the ratio of acetic acid to propionic acid, mainly derived from an increase of the molar proportion of the latter. Reductions of this ratio associated with increases of the propionic acid concentrations by the inclusion of malate in the diet have been reported previously in several in vitro studies $[7,8]$. On the contrary, the in vivo results of Kung et al. [15] did not show an increase in the propionic acid concentrations. In our study, the benefits associated with the addition of malate were only moderate.

In summary, the treatments combining the application of malic acid solutions and heat are promising since they led to a deceleration of the CP degradation of SBM, without negative effects on the ID of the undegraded protein or the ED of DM. As a consequence, the microbial protein synthesis from this feed in the rumen might be assumed to be unaffected. The potential of these treatments to improve the SBM protein value may be higher for samples with SBM degradation characteristics within the usual ranges. The inclusion in the diet of malic acid with heat treated SBM had no effect on the fibrolytic activity and reduced the acetic acid to propionic acid ratio in the rumen. Finally, malic acid doses higher than $60 \mathrm{~g} \cdot \mathrm{kg}^{-1}$ of SBM (equivalent to $0.26 \%$ on the diet) did not 
provide additional benefits on protein protection or digestion efficiency.

\section{ACKNOWLEDGEMENTS}

This work has been supported by the CICYT funded Project AGL 2001-3662.

\section{REFERENCES}

[1] Andres S., González J., Relations entre la dégradabilité in sacco des matières azotées des tourteaux de soja et leur composition chimique, Ann. Zootech. 41 (1992) 19.

[2] Andrieu J., Demarquilly C., Sauvant D., Tables de la valeur nutritive des aliments, in: Jarrige R. (Ed.), Alimentation des Bovins Ovins \& Caprins, INRA, Paris, 1988, pp. 351-434.

[3] Arroyo J.M., González J., Alvir M.R., Rodríguez C.A., Ouarti M., Protección frente a la degradación ruminal de la harina de girasol mediante el tratamiento con ácidos y calor, Información Técnica Económica Agraria 26 (Suppl.) (2005) 542-544.

[4] Association of Official Analytical Chemists, Official Methods of Analysis, 15th ed., Association of Official Analytical Chemists, Washington, DC, 1990.

[5] Atwal A.S., Milligan L.P., Young B.A., Effects of volatile fatty acid treatment on the protection of protein in the rumen, Can. J. Anim. Sci. 54 (1974) 393-401.

[6] de Boer G., Murphy J.J., Kennelly J.J., Mobile nylon bag for estimating intestinal availability of rumen undegradable protein, J. Dairy Sci. 70 (1987) 977-982.

[7] Carro M.D., Lopez S., Valdés C., Ovejero F.J., Effect of DL-malate on mixed ruminal microorganism fermentation using the rumen simulation technique/(RUSITEC), Anim. Feed Sci. Tech. 79 (1999) 279-288.

[8] Carro M.D., Ranilla M.J., Effect of the addition of malate on in vitro rumen fermentation of cereal grains, Brit. J. Nutr. 89 (2003) 181188.

[9] Deacon M.A., de Boer G., Kennelly J.J., Influence of Jet-Sploding and extrusion on ruminal and intestinal disappearance of canola and soybeans, J. Dairy Sci. 71 (1988) 745-753.

[10] Gomez G., Degradabilidad ruminal de los ensilados de hierba y maiz, Escuela Técnica Superior de Ingenieros Agrónomos, Universidad Politécnica, Madrid, Spain, Ph.D. Thesis, 1998, 329 p.

[11] González J., Rodríguez C.A., Andrés S.G., Alvir M.R., Rumen degradability and microbial contamination of fish meal and meat meal measured by the in situ technique, Anim. Feed Sci. Tech. 73 (1998) 71-84.

[12] González J., Rodríguez C.A., Andrés S.G., Alvir M.R., In situ evaluation of the protein value of soybean meal and processed full fat soybeans for ruminants, Anim. Res. 51 (2002) 455-464.

[13] Grovum W.L., Williams V.J., Rate of passage of digesta in sheep. 4. Passage of marker through the alimentary tract and the biological relevance of rate-constants derived from the changes in concentration of marker in faeces, Brit. J. Nutr. 30 (1973) 313-329.

[14] Hvelplund T., Digestibility of rumen microbial protein and undegraded dietary protein estimated in the small intestine of sheep and by in sacco procedure, Acta Agric. Scand. 25 (Suppl.) (1985) 132-144.

[15] Kung L. Jr., Huber J.T., Krummrey J.D., Allison L., Cook R.M., Influence of adding malic acid to dairy cattle rations on milk production, rumen volatile acids, digestibility, and nitrogen utilization, J. Dairy Sci. 65 (1982) 1170-1174.

[16] National Research Council, Nutrients Requirements of Dairy Cattle, Seventh revised edition, National Academy Press, Washington, DC, 2001.

[17] Nisbert D.J., Martin S.A., Effect of dicarboxilic acids and Aspergillus Oryzae fermentation extract on lactate uptake by the ruminal bacterium Selenomonas ruminantium, Appl. Environ. Microb. 56 (1990) 3515-3518.

[18] Nisbert D.J., Martin S.A., Effect of a Sacchromyces cerevisiae culture on lactate utilization by the ruminal bacterium Selenomonas ruminantium, J. Anim. Sci. 69 (1991) 4628-4633.

[19] Ørskov E.R., McDonald I., The estimation of protein degradability in the rumen from incubation measurements weighted according to rate of passage, J. Agr. Sci. 92 (1979) 499503. 
[20] Pereira J.C., Carro M.D., González J., Alvir M.R., Rodríguez C.A., Rumen degradability and intestinal digestibility of brewers' grains as affected by origin and heat treatment and of barley rootlets, Anim. Feed Sci. Tech. 74 (1998) 107-121.

[21] Robertson J.B., Van Soest P.J., The detergent system of analysis and its application to human foods, in: James W.P.T., Theander O. (Eds.), The Analysis of Dietary Fibre in Food, Marcel Dekker, New York, 1981, pp. 123-158.

[22] Sauvant D., Perez J.M., Tran G., Tables de composition et de valeur nutritive des matières premières destinées aux animaux d'élevage, INRA Editions, Paris, 2001.

[23] Van Milgen J., Baumont R., Models based on variable fractional digestion rates to describe ruminal in situ digestion, Brit. J. Nutr. 73 (1995) 793-807.
[24] Van Soest P.J., Robertson J.B., Lewis B.A., Methods for dietary fiber, neutral detergent fiber and nonstarch polysaccharides in relation to animal nutrition, J. Dairy Sci. 74 (1991) 3583-3597.

[25] Vincini J.L., Clark J.H., Crooker B.A., Effectiveness of acetic acid and formaldehyde for preventing protein degradation in the rumen, J. Dairy Sci. 66 (1983) 350-354.

[26] Waltz D.M., Loerch S.C., Effect of acid and alkali treatment of soybean meal on nitrogen utilization by ruminants, J. Anim. Sci. 63 (1986) 879-887.

[27] Yang W.Z., Poncet C., Mesure de la digestion de l'azote alimentaire dans les différentes parties du tube digestif du mouton par la technique des sachets de Nylon, Reprod. Nutr. Dev. 28 (Suppl. 1) (1988) 125126. 
